\title{
Effect of Turbulent Flow on Corrosion Behavior of 6.5Cr Steel in $\mathrm{CO}_{2}$-Containing Environment
}

\author{
Bei Wang ${ }^{1 *}$, Yun Wang ${ }^{1}$, Qingping $\mathrm{Li}^{2}$, Lihua Hu${ }^{2}$, Wei Chang ${ }^{2}, H$ uixin Li $^{2}$, Minxu Lu ${ }^{1}$ \\ ${ }^{1}$ University of Science and Technology Beijing, Beijing 100083, China \\ ${ }^{2}$ CNOOC Research Institute, Beijing, 100028, China \\ "E-mail: 247776086@qq.com
}

doi: $10.20964 / 2021.03 .25$

Received: 29 April 2020 / Accepted: 29 December 2020 / Published: 31 January 2021

\begin{abstract}
The effect of turbulent flow on the corrosion behavior of $6.5 \mathrm{Cr}$ steel in $\mathrm{CO}_{2}$-saturated oil field formation water was examined using a rotating cylinder electrode. Electrochemical measurements demonstrated that increasing the flow rate could decrease the corrosion rate of $6.5 \mathrm{Cr}$ steel. When the rotation rate of the rotating cylinder electrode reached $2000 \mathrm{rpm}, 6.5 \mathrm{Cr}$ steel could be passivated. Surface characterization and ion analysis results showed that increasing flow rate reduced $\mathrm{Fe}^{2+}$ concentration in the solution near the steel surface, inhibited $\mathrm{FeCO}_{3}$ deposition, and then increased $\mathrm{Cr}(\mathrm{OH})_{3}$ concentration in a corrosion film.
\end{abstract}

Keywords: Cr-bearing alloy steel, Rotating cylinder electrode, $\mathrm{CO}_{2}$ corrosion, Passivity, Flow rate

\section{$\underline{\text { FULL TEXT }}$}

(C) 2021 The Authors. Published by ESG (www.electrochemsci.org). This article is an open access article distributed under the terms and conditions of the Creative Commons Attribution license (http://creativecommons.org/licenses/by/4.0/). 